\title{
Continuing vocational training and innovation in Europe
}

ARTICLE in INTERNATIONAL JOURNAL OF INNOVATION AND LEARNING · JUNE 2012

DOI: 10.1504/IJIL.2012.047135

CITATIONS

2

2 AUTHORS:

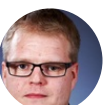

Teemu Makkonen

University of Surrey

21 PUBLICATIONS 17 CITATIONS

SEE PROFILE

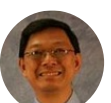

Binshan Lin

Louisiana State University in Shreveport

211 PUBLICATIONS 2,297 CITATIONS

SEE PROFILE 


\title{
Continuing vocational training and innovation in Europe
}

\author{
Teemu Makkonen \\ Department of Geosciences and Geography \\ University of Helsinki \\ PO Box 64, FI-00014 University of Helsinki, Finland \\ E-mail: teemu.makkonen@helsinki.fi \\ Dr. Binshan Lin* \\ Business School \\ Louisiana State University in Shreveport \\ One University Place, Shreveport, LA 71115, USA \\ E-mail: Binshan.lin@1sus.edu \\ *Corresponding author
}

\begin{abstract}
This paper hypothesises that continuing vocational training (CVT) should have a positive effect on the innovativeness of nations. Using correlation analysis and several variables from the continuing vocational training survey (CVTS), which depicts various aspects of CVT, the hypothesis of a positive connection between CVT and innovation, as measured in patents, is confirmed in the European context: those nations where the commitment to CVT is the highest are also the most innovative countries in Europe. Consequently, investments and commitment to CVT, when properly planned and executed, have a positive effect on the innovativeness of firms and, subsequently, nations.
\end{abstract}

Keywords: continuing vocational training, innovation, learning, patents

Biographical notes: M.Sc. Teemu Makkonen is currently a PhD student at the department of Geosciences and Geography, University of Helsinki. He is currently pursuing his doctorate degree in the area of economic geography.

Dr. Binshan Lin is the BellSouth Corporation Professor at College of Business Administration, Louisiana State University in Shreveport. He received his $\mathrm{PhD}$ from the Louisiana State University in 1988. Professor Lin has published over 230 articles in refereed journals.

This is an Accepted Manuscript of an article published by Inderscience in International Journal of Innovation and Learning on June 4, 2012, Vol. 9, No. 4, pp. 325338. Available online: http://dx.doi.org/10.1504/IJIL.2012.047135 


\section{$1 \quad$ Introduction}

Innovation is considered one of the key factors behind the growth of firms and, subsequently, the growth of regions and nations (Gu and Tang, 2004; Pinto, 2009). On the other hand, human capital and skills have been frequently raised as the cornerstones upon which innovations are built (Leiponen, 2005; Schneider, Günther, and Brandenburg, 2010). A capable workforce thus significantly enhances the innovativeness of firms and nations. Learning and training must therefore be considered important factors contributing to the overall innovativeness of nations. With these things in mind, a connection ought to exist between continuing vocational training (CVT) and the innovative performance of firms and, subsequently, nations. CVT has increasingly gained attention from both work organisations and governments, as it is one of the means for meeting the strategic goals for the European Union (EU) to become the most competitive knowledge-based society in the world (Buyens and Wouters, 2005). Interestingly, despite the current emphasis on it, CVT has been considered the weakest link in attaining the lifelong learning goals set by the EU (Tessaring and Wannan, 2004). Consequently, research on the subject is needed, for the existing literature on CVT is relatively scarce and even fewer previous studies have explored the topic of the linkages between CVT and innovation.

This paper aims to explore the connection between CVT and innovations on the national level among the countries of the EU (except Cyprus, Malta, and Slovakia) and Norway by using patent statistics and variables from Eurostat's Continuing Vocational Training Survey (CVTS). The incentive here is to analyse whether the vocational training activities of individual firms can affect the innovativeness of their home countries. This paper hypothesises that CVT and innovation are indeed positive- 
ly connected. The research questions, which are tested in the European context, are as follows:

1) Is there a positive connection between CVT and innovative activities?

2) Do some variables describing CVT predict innovation better than others?

To answer these questions, a comparison is drawn of which countries in Europe invest the most in CVT and which are the most innovative. The results are then discussed in relation to the economic conditions of the nations under study, as the economic development level of countries likely influences their innovativeness and the availability of resources for CVT.

\section{$2 \quad$ Literature review}

Human capital has gained an increasing amount of attention in recent studies, as its effects on performance, productivity and growth have been duly recognised. There is little doubt that human capital positively affects firms' performance and on a larger scale, stimulates the economic growth of nations. Investment in skills through the training of employees seems to be a well advised means of gaining advantage over rivals. The role of education and training is thus increasingly viewed as the target of development policy with the most potential (de Bruijn and Lagendijk, 2005). The justification behind this logic is that human capital is considered an enabler in profitable innovation, and investments in skills help to expand the group of firms in the national economy that have the potential to innovate successfully (Leiponen, 2005). Innovation, on the other hand, is believed to be a key factor behind productivity growth on the firm level and economic growth on the national level (Gu and Tang, 2004; Pinto, 2009). Accordingly, as the presence of educated/skilled human capital bolsters the 
innovative output of regions and creates greater economic activity (Ewers, 2007; Glaeser, 2000), measures targeted to enhance the skills of employees and their capabilities to innovate, such as CVT, deserve the proper attention of researchers and policymakers.

Two concepts are frequently used in the literature on the topic of this paper: learning and training. Learning can be understood from the viewpoint of an individual as the acquisition of new skills and knowledge. Another related concept in frequent use is that of organisational learning. Organisational learning can be defined as the collective capability of organisations to acquire, share, and utilise knowledge (Aragón-Correa, García-Morales, and Cordón-Pozo, 2007). Still, because organisations consist of individuals, organisational learning does not pre-empt the viewpoint of human capital and skills as characteristics related to individuals. Training, on the other hand, is most commonly understood as the teaching of vocational (or practical) skills. The objective of training should be viewed as a lifelong process in which individuals continuously strive to cultivate their vocational skills. Accordingly, the term CVT has gained an increasing amount of attention in recent discussions of vocational education and training (VET). CVT is not narrowly defined, so it can assume multiple forms from short courses to longer programmes, which can be organised by companies, organisations or governmental bodies (Tessaring and Wannan, 2004). Firms have well recognised the potential that CVT has to offer. One example of this is in Slovenia, where the workplace is perceived as an important location and source for learning because native companies are, logically, interested in the development of well-skilled workers (Gomezelj Omerzel, Fister, and Trunk Širca, 2008). A further example of the greater interest in CVT is Eurostat's CVTS of carried out in 1993, 1999 and 2005. 
As such, learning and CVT are positively associated with firm-level performance and productivity as well as with the creation of competitive advantage (Bontis, Crossan, and Hulland, 2002; Melton, Chen, and Lin, 2006; Prieto and Revilla, 2002; Zwick, 2005). However, the interactions between innovation, learning, and performance are multiform (see Akgün et al., 2007; Aragón-Correa, García-Morales, and Cordón-Pozo, 2007; Weerawardena, O'Cass, and Julian, 2006). Organisational learning has a strong direct influence on innovation, and additionally, innovation positively and significantly influences performance. Organisational learning also positively affects performance, but mainly through innovation. Organisations should therefore focus on organisational learning when formulating and assessing measures for promoting innovation and achieving better performance (Liao, Fei, and Liu, 2008). On a more underlying level, Cohen and Levinthal (1989) have demonstrated that the ease of learning will affect firms' incentives to conduct research and development (R\&D), which is a premise for innovation (e.g. Tödtling, Lehner, and Trippl, 2006). Furthermore, a positive learning climate is beneficial to firms aspiring to be innovative (Calantone, Cavusgil, and Zhao, 2002). In light of the above evidence, it comes as no surprise that numerous previous studies have emphasised the influence of learning in the innovation performance of organisations (Alegre and Chiva, 2008; Amara et al., 2008; García-Morales, Lloréns-Montes, and Verdú-Jover, 2007) and regions (Hauser, Tappainer, and Walde, 2007; Morgan, 1997). In fact, innovation actually seems to depend on a company's capacity to learn (Alegre and Chiva, 2008; Weerawardena, O'Cass, and Julian, 2006). In particular, interactive learning with customers and suppliers is positively associated with the innovation activities of firms (Meeus, Oerlemand, and Hage, 2001). In conclusion, drawing from the existing literature, learning seems to have a positive effect on the performance, productivity and growth of firms, and sub- 
sequently nations, through its strong impact on the innovative capacities of employees.

Education is closely linked to innovation. Empirical studies have confirmed this through showing that the more a society invests in its education, the higher the educational level of a region and its innovation activity output (Varsakelis, 2006). However, since firms are the main actors who account for the bulk of innovation most of the qualifications acquired through higher education will be relatively general, the qualifications an employee acquires through CVT will be more firm-specific. Furthermore, some of this training will be targeted to respond to the firm's requirements in terms of ongoing innovation and these forms of firm-specific training are key complementary resources in the development of the firm's capacity for innovation (Lorenz, 2006).

Previous studies on training and innovation have demonstrated that positive connections exist between them. For example, Amara et al. (2008) have shown that learning through training has a high impact on the degree of novelty of innovation in firms. Furthermore, Freel (2005) has demonstrated with a sample of small firms that the most innovative firms train more staff and that innovation and training are linked. Of course, training programmes are not equally useful for all firms (Johnson, Baldwin, and Diverty, 1996), and some training programmes that are organised from above and do not take into consideration the needs of the firms seem to fail altogether (MacDonald, Assimakopoulos, and Anderson, 2007). What matters is that the learning and training policies aim not do adopt models from others, but rather develop their own indigenous modes best suited to the needs of the target group in focus (see Lorenzen, 2001). There are also differences in the effectiveness of CVT according to training forms: formal external training yields the highest productivity increase in es- 
tablishments, and on-the-job training even seems to have a negative impact on productivity (Zwick, 2005). Furthermore, Barrett and O’Connell (2001) have demonstrated that the effect of general training on productivity growth is statistically significant, whereas they found no evidence of similar effects related to specific training. Despite these limitations, on a general level the existing literature on CVT and on the closely linked topic of learning seems to support the first hypothesis proposed in this paper: that CVT should have a positive effect on innovation.

Because the innovative capabilities of nations differ according to their characteristics and economic conditions (Faber and Hesen, 2004), innovation is unevenly distributed across the geographical landscape in general (Moodyson, Coenen, and Asheim, 2008), and across Europe in particular (Copus, Skuras, and Tsegenidi, 2008; Fagerberg and Srholec, 2008). This means that in innovative activities, the more welloff nations usually have the advantage over the more economically disadvantaged countries, although some nations do not perform as well on innovative output indicators as their investment in innovation and their economic conditions would suggest (Hinloopen, 2003). Similarly, the emphasis on CVT and the effects of CVT on innovation are also likely to vary between nations. For example, a previous comparative study (Brockmann, Clarke, and Winch, 2008) has shown that major distinctions exist between the 'knowledge-based' VET models of Germany and the Netherlands and the 'skills-based' VET model of England. However, the underlying trend between CVT and innovation should be visible despite these country-specific characteristics. Regarding the maps of innovation and CVT in Europe, it is that the more economically developed counties likely excel in these two dimensions also, as both are also, at least according to the existing literature, likely to be affected by the economic condition of a given country. 


\section{$3 \quad$ Data and methods consideration}

\subsection{Patents as an indicator and CVT as an antecedent of innovation}

Patents frequently serve as a proxy indicator of innovation, although their use as an indicator of innovation has its shortcomings (see e.g. Arundel and Kabla, 1998; Brouwer and Kleinknecht, 1999; Coad and Rao, 2008; Ratanawaraha and Polenske, 2007; Santarelli and Piergiovanni, 1996): certain sectors are unsuitable for patent application, and not all firms make the effort to claim patents as other means of appropriation are also available. Furthermore, the range of patentable innovations constitutes only a subset of all research outcomes. Because innovation is considered an invention that is introduced into the market (see Fagerberg, 2005), the fact that not every registered patent is actually applied for and used (i.e. patents measure the result of an invention rather than true innovation) and that the quality of individual patents varies widely - some inventions are extremely valuable, whereas others are of almost no commercial value - constitute an additional problem in using patents as an indicator of innovation. Still, innovation is more probable when the numbers of patent applications per population are higher (Sternberg and Arndt, 2001), and a firm's innovative output systematically correlates with its actual patenting behaviour (Brouwer and Kleinknecht, 1999). Thus, one can conclude that patents are a good, if imperfect, proxy for innovation that has been used and compared to other innovation indicators in numerous previous studies (e.g. Acs and Audretsch, 1989; Gössling and Rutten, 2007; Hagedoorn and Cloodt, 2003) with fairly good results, indicating that, at least in a statistical sense, there is not much difference between the distinct indicators (R\&D 
is also a commonly used proxy for innovation in addition to patents) used in measuring innovation.

As described in the previous section, CVT appears to be an antecedent of innovation (e.g. Freel, 2005). To test the hypothesis proposed in this paper, a number of indicators from the CVTS, which includes several parameters from various perspectives, had to be chosen to present the most important aspects of CVT. The variables used here to depict CVT, all of which all are considered the main variables of the CVTS (e.g. Statistics Finland, 2010), are:

1) Percentage of enterprises providing CVT courses,

2) Percentage of employees participating in CVT courses,

3) Hours in CVT courses per employee, and

4) Cost of CVT courses as a percentage of total labour costs.

The data are not without problems, however, and some ambiguity surrounds the definition of CVT (discussed in greater detail in Buyens and Wouters, [2005]). In addition, the statistical authorities of Finland (Statistics Finland, 2010) consider incomparable the cost figure for CVT courses as a percentage of total labour costs in the United Kingdom, and have omitted it from their own CVTS tables, a decision not made in this paper. The decision was made after ensuring that any possible error with one indicator in one country does not altogether skew the analysis carried out in this paper (in fact the impact was almost negligible). Drawing from the literature on innovation indicators, it seems plausible that the variables chosen in this study to represent CVT also show no significant differences between their capabilities to predict innovation, as they all measure the same phenomenon, though from slightly different viewpoints. 


\subsection{Data sources and methods}

The data used in this study were collected from the databases of Eurostat (2010), arguably the best source of comparable data on the EU countries. The patent data present the patents granted by the United States Patent and Trademark Office (USPTO) per million inhabitants as an average for the years 2000-2004 (a standard procedure to smooth the data, as the number of patents can vary significantly across individual years), and the CVT variables were collected from the CVTS from 1999. As described above, patents served here as a proxy for innovation. The choice to use the older CVTS study from 1999 instead of the more recent CVTS carried out in 2005 was made in accordance with the existing literature. The logic behind this procedure lies in the findings of Zwick (2005), who demonstrated that the productivity pay-off of the training investment may reveal itself only in future. As the most recent years are not yet available in the patent statistics database of Eurostat, there is little point in comparing the newer results of the CVTS to the patent data preceding them.

The data cover all the current countries of the EU and Norway, with the exception of Cyprus, Malta, and Slovakia, which were excluded from the analysis due to missing data on most of the variables used here. In addition to the comparisons of individual variables depicting CVT, the variables were arranged as rankings from the largest to the smallest percentages or investments by country. The countries were assigned points according to their order in the rankings, and these points were combined to yield a sum variable. The sum variable, as well as individual variables, of the CVT of each country was then compared using correlation analysis to the number of patents granted to each country. 
The sum variable could have been replaced with a composite measure of CVT produced, for example, by principal component analysis (PCA). However, the data used here are rather thin for a successful PCA, and in fact the composite measure, produced by PCA, functions similarly to the sum variable (because the standings of countries in the rankings of the composite measure and sum variable were the same). Thus, we decided to use the simpler sum variable.

Furthermore, because innovation, and presumably CVT also, appear to be linked to the economic conditions of a given country (e.g. Faber and Hesen, 2004), innovation and CVT indicators were also compared to gross domestic product (GDP). GDP, despite its limitations, is a commonly used indicator of the economic conditions of a given country (measured here in Euros per inhabitant as an average from 19992004). As the patent data used here do not follow a normal distribution, Spearman's correlation analysis was used to explore the possible interconnection of CVT, innovation and GDP. Descriptions of different correlation indices can be found in Chen and Popovich (2002).

\section{$4 \quad$ Results and discussion}

The results quite clearly show that a positive connection exists between CVT and innovation. Countries where firms invest heavily in CVT also appear to be those which register the most patents. The correlation between the sum variable depicting CVT and innovation is positive, strong, and statistically highly significant (Spearman's correlation coefficient $=0.824$, p-value $<0.001$ ). The correlations of individual variables of CVT suggest that every variable tested in this paper has a statistically significant correlation with innovation (i.e. the patent statistics) (Table 1). From the individual 
variable of CVT, hours in CVT courses per employee shows the highest correlation coefficient, higher in fact than even the constructed sum variable (see also Figure 1).

Table 1. Spearman's correlation coefficients and p-values between innovation and variables depicting CVT.

Figure 1. Standings of countries in the rankings of innovation and sum variable of CVT (left) and innovation and hours in CVT courses (right) (see also Appendix 1).

The above mentioned analyses demonstrate that CVT affects the innovativeness of countries, as patents serve here as an indicator of innovation. The hypothesis set in this thus holds true. To answer the first research question, CVT and innovation do indeed have a positive connection. The country rankings of innovation, as measured in patents, and CVT, measured as a sum variable, confirm the conclusion that countries with high scores in CVT rankings are also the most innovative nations of Europe (Figure 2; see also Appendix 1). Thus steps to promote CVT can also be seen as steps to enhance the innovativeness of firms and nations. As already stated above, CVT works as an important complementary resource in the development of the firm's capacity for innovation. CVT can be seen as a tool to create innovation. Higher education might be the most prominent factor affecting the innovativeness of firms and subsequently nations, but it is targeted to general qualifications whereas the firm-specific goals of CVT can directly influence the firm's ongoing innovation processes. Furthermore, as the variables used here all show highly significant correlations with innovation, the variable used seems to have little statistical impact on the analysis. The fact that the individual variables depicting CVT heavily correlate with each other further supports this notion. Thus, to answer the second research question: there is no 
significant difference between the distinct variables of CVT used in this study to predict innovation.

Figure 2. Standings of the counties in the rankings of A) innovation (as measured in patents), B) $C V T$, and C) GDP.

The only significant exceptions to the rule of the 'interconnectedness of innovation and CVT' are the Czech Republic and Germany. In the Czech Republic, the relatively heavy investment in CVT is reflected less clearly in the patent statistics than it does in other countries. Thus, the effects of CVT in the Czech Republic may not yet be evident in the form of its innovations as a number of obstacles arose in adopting the innovation policies of the EU. Furthermore, the Czech Republic seems to have made insufficient effort to identify the sectors with the greatest innovative potential. For example, Prague's gastronomic education cluster, where practical training was offered for school-leavers, whose contribution to innovation creation may be questionable, was selected as a priority project (Blažek and Uhlír̆, 2007). On the other hand, Germany offers an exception that is the exact opposite of the situation in the Czech Republic. The high standing of Germany in the innovative ranking does not coincide with weaker standing in the CVT ranking, which may stem from the partial failure of vocational training programmes in East Germany. The envisaged provision of 'best practices' in vocational training from other EU member states to East Germany has been only partly successful, because also problems in the training sector in the West were exported to the East (Ertl 2000; see also Fitzenberger and Prey, 2000; Lechner, 2001; Pischke, 2001). Thus, as Lorenzen (2001) stated, training policies should not aim to adopt models from others, but to develop indigenous modes that are best suited 
to the needs of the region in focus. In general, the fact that the differences between East and West Germany during the time of the data collection of the CVTS in 1999 were still relatively large may have skewed the statistics, as East and West Germany were treated as a whole.

The countries that perform well in innovation and CVT rankings are the wealthier nations of Europe at least in economic terms, thus implying that economic conditions play a role in the CVT activities of European countries (Figure 2; see also Appendix 1). As Gössling and Rutten (2007) propose, innovation stimulates economic development, and a certain stage of economic development is necessary to generate innovation. This could mean that 'vicious dynamics' influence these different measures: economic conditions affect the number of CVT activities within countries, which affects the rate of innovation, which in turn translates into economic growth. This renders the situation challenging for the less developed countries to catch-up to the more developed countries in the global market. Moreover, economic conditions have a more straightforward effect on innovativeness through a greater ability to invest in R\&D and education, for example (see Faber and Hesen, 2004), as CVT is by no means the only way to enhance the innovativeness of nations. These notions are further supported by the fact that GDP shows a statistically significant correlation between both innovation, as measured in the number of patents (Spearman's correlation coefficient $=0.843, \mathrm{p}$-value $<0.001)$ and the sum variable of CVT (Spearman's correlation coefficient $=0.840$, -value $<0.001$ ) 


\section{Conclusions}

The analyses in this paper suggest that CVT and innovation have a positive connection. The countries of Europe where firms are committed to CVT are also the most innovative. CVT should therefore be, and in many cases is, considered an important factor affecting the innovativeness of firms and, subsequently, nations. Thus, to answer the first research question, CVT and innovation do indeed share a positive connection. The hypothesis presented in this paper thus appears to hold true. The correlation coefficients deviated only slightly between innovation and the distinct variables of CVT as well as the sum variable of CVT. Accordingly, to answer the second research question; there is no evident difference between the distinct variables of CVT used in this study to predict innovation. CVT and innovation are manifestation of economic conditions, however, and the interconnectedness between them is complex, as they are all linked to each other: economic condition correlates highly with both CVT and innovation, as does CVT with innovation. Economic conditions seem to affect the number of CVT activities within countries, which itself affects the rate of innovation, which in turn translates into economic growth. Furthermore, economic development also affects the rate of innovation more directly through $R \& D$ and investments in human capital. Thus, the links between economic development and innovation deserve analysis in greater detail in further studies.

In conclusion, investment in CVT seems to have a positive effect on the innovativeness of firms and, subsequently, nations and is therefore expedient for firms (and countries) striving to be more innovative. Of course, investment in training does not automatically lead to better innovative capacities, and other factors, such as education, also influence the innovativeness of firms and nations. Therefore, firms and 
nations should employ caution and proper planning, as previous studies (MacDonald, Assimakopoulos, and Anderson, 2007) have shown that if policy decisions fail to take into account the opinions of firms, the government investments in CVT seldom yield the desired results. Moreover, the example from the Czech Republic suggests that other nations should use caution in deciding which sectors to promote: if the goal is to enhance the innovativeness of firms within the country, then sectors that can truly be innovative should receive support. On the other hand, the case of East Germany warns us not to adopt training policies and models from others as such, but to develop indigenous modes best suited to the needs of the target group or region in focus. When properly planned and executed, however, commitment to and investments in CVT yield desirable results that are evident in innovation statistics.

It is worth noting that these results should be discussed with some caution, as the CVTS data and the usage of patent data as indicators of innovation have their limitations. Furthermore, as the analysis covers only certain aspects of the topic, further investigation is needed into the effects of CVT. However, despite these limitations, the results presented in this paper are nevertheless clear, as the analysed correlations were strong and statistically highly significant.

\section{Acknowledgement}

This work is a part of the project 127213 funded by the Academy of Finland. The authors thank also Dr. Gareth Rice and the anonymous reviewers for their comments improving the paper. 


\section{References}

Acs, Z. and Audretsch, D. (1989) 'Patents as a measure of innovative activity', Kyklos, Vol. 43, No. 2, pp.171-180.

Akgün, A., Keskin, H., Byrne, J. and Aren, S. (2007) 'Emotional learning capability and their impact on product innovativeness and firm performance', Technovation, Vol. 27, pp. $501-513$

Alegre, J. and Chiva, R. (2008) 'Assessing the impact of organizational learning capability on product innovation performance: An empirical test', Technovation, Vol. 28, pp.315-326.

Amara, N., Landry, R., Becheikh, N. and Ouimet, M. (2008) 'Learning and novelty of innovation in established manufacturing SMEs', Technovation, Vol. 28, pp.450-463.

Aragón-Correa, J.A., García-Morales, V. and Cordón-Pozo, E. (2007) 'Leadership and organizational learning's role on innovation and performance: Lessons from Spain', Industrial Marketing Management, Vol. 36, pp.349-359.

Arundel, A. and Kabla, I. (1998) 'What percentage of innovations are patented? Empirical estimates for European firms', Research Policy, Vol. 27, pp.127-141.

Barrett, A. and O'Connell, P. (2001) 'Does training generally work? The returns to incompany training', Industrial and Labor Relations Review, Vol. 54, No. 3, pp.647-662.

Blažek, J. and Uhlíŕ, D. (2007) 'Regional innovation policies in the Czech Republic and the case of Prague: An emerging role of a regional level?', European Planning Studies, Vol. 15, No. 7, pp.871-888.

Bontis, N., Crossan, M. and Hulland, J. (2002) 'Managing an organizational learning system by aligning stocks and flows', Journal of Management Studies, Vol. 39, No. 4, pp.437469.

Brockmann, M., Clarke, L. and Winch, C. (2008) 'Knowledge, skills, competence: European divergences in vocational education and training (VET) - The English, German and Dutch cases', Oxford Review of Education, Vol. 34, No. 5, pp.547-567. 
Brouwer, E. and Kleinknecht, A. (1999) 'Innovative output and a firm's propensity to patent. An exploration of CIS micro data', Research Policy, Vol. 28, pp.615-624.

Buyens, D. and Wouters, K. (2005) 'Continuing vocational training in Belgian companies', Journal of European Industrial Training, Vol. 29, No. 4, pp. 312-335.

Calantone, R., Cavusgil, S.T. and Zhao, Y. (2002) 'Learning orientation, firm innovation capability and firm performance', Industrial Marketing Management, Vol. 31, pp.515-524.

Chen, P. and Popovich, P. (2002) Correlation. Parametric and nonparametric measures, Thousand Oaks: Sage Publications.

Coad, A. and Rao, R. (2008) 'Innovation and firm growth in high-tech sectors: A quantile regression approach', Research Policy, Vol. 37, pp.633-648.

Cohen, W. and Levinthal, D. (1989) 'Innovation and learning: The two faces of R\&D', The Economic Journal, Vol. 99, pp. 569-596.

Copus, A., Skuras, D. and Tsegenidi, K. (2008) 'Innovation and peripherality: An empirical comparative study of SMEs in six European Union member countries', Economic Geography, Vol. 84, No. 1, pp.51-82.

de Bruijn, P. and Lagendijk, A. (2005) 'Regional innovation systems in the Lisbon strategy', European Planning Studies, Vol. 13, No. 8, pp.1153-1172.

Ertl, H. (2000) 'The transition of vocational education and training in Eastern Germany: Notes on the role of European Union programs', Comparative Education Review, Vol. 44, No. 4, pp.464-492.

Eurostat (2010) Statistics database. Obtained through the Internet: http://epp.eurostat.ec. europa.eu [accessed 20/5/2010].

Ewers, M. (2007) 'Migrants, markets and multinationals: Competition among world cities for the highly skilled', GeoJournal, Vol. 68, pp.119-130.

Faber, J. and Hesen, A.B. (2004) 'Innovation capabilities of European Nations. Cross-national analyses of patents and sales of product innovations', Research Policy, Vol. 33, pp.193207. 
Fagerberg, J. (2005) 'Innovation: A guide to the literature', In: Fagerberg, J., Mowery, D. and Nelson, R. (eds.), The Oxford handbook of innovation, (pp.1-26), Oxford: Oxford University Press.

Fagerberg, J. and Srholec, M. (2008) 'National innovation systems, capabilities and economic development', Research Policy, Vol. 37, pp.1417-1435.

Fitzenberger, B. and Prey, H. (2000) 'Evaluating public sector sponsored training in East Germany', Oxford Economic Papers, Vol. 52, No. 3, pp.497-520.

Freel, M. (2005) 'Patterns of innovation and skills in small firms', Technovation, Vol. 25, pp.123-134.

García-Morales, V., Lloréns-Montes, F.J. and Verdú-Jover, A. (2007) 'Influence of personal mastery on organizational performance through organizational learning and innovation in large firms and SMEs', Technovation, Vol. 27, pp.547-568.

Glaeser, E. (2000) 'The new economics of urban and regional growth', In: Clark, G., Feldman, M. and Gertler, M. (eds.), The Oxford handbook of economic geography, (pp.8398), Oxford: Oxford University Press.

Gomezelj Omerzel, D., Fister, K. and Trunk Širca, N. (2008). 'The support of employers in the system of workplace learning recognition', International Journal of Innovation and Learning, Vol. 5, No. 1, pp.38-50.

Gu, W. and Tang, J. (2004) 'Link between innovation and productivity in Canadian manufacturing industries', Economics of Innovation and New Technology, Vol. 13, No. 7, pp.671-686.

Gössling, T. and Rutten, R. (2007) 'Innovation in regions', European Planning Studies, Vol. 15, No. 2, pp.253-270.

Hagedoorn, J. and Cloodt, M. (2003) 'Measuring innovative performance: Is there an advantage in using multiple indicators?', Research Policy, Vol. 32, pp.1365-1379.

Hauser, C., Tappainer, G. and Walde, J. (2007). 'The learning region: The impact of social capital and weak ties on innovation', Regional Studies, Vol. 41, No. 1, pp.75-88. 
Hinloopen, J. (2003) 'Innovation performance across Europe', Economics of Innovation and New Technology, Vol. 12, No. 2, pp.145-161.

Johnson, J., Baldwin, J. and Diverty, B. (1996) 'The implications of innovation for human resource strategies', Futures, Vol. 28, No. 2, pp.103-119.

Lechner, M. (2001). 'An evaluation of public-sector-sponsored continuous vocational training programs in East Germany', The Journal of Human Resources, Vol. 53, No. 2, pp.347375.

Leiponen, A. (2005) 'Skills and innovation', International Journal of Industrial Organization, Vol. 23, pp.303-323.

Liao, S-h., Fei, W-C. and Liu, C-T. (2008) 'Relationships between knowledge inertia, organizational learning and organizational innovation', Technovation, Vol. 28, pp.183-195.

Lorenz, E. (2006) 'The organisation of work, education and training, and innovation'. Keynote presentation prepared for the conference on Education, innovation and development. November 27-28, 2006. Lisbon.

Lorenzen, M. (2001) 'Localized learning an policy: Academic advice on enhancing regional competiveness through learning', European Planning Studies, Vol. 9, No. 2, pp.163185.

MacDonald, S., Assimakopoulos, D. and Anderson, P. (2007) 'Education and training for innovation in SMEs', International Small Business Journal, Vol. 25, No. 1, pp.77-95.

Meeus, M., Oerlemans, L. and Hage, J. (2001) 'Patterns of interactive learning in high-tech region', Organization Studies, Vol. 22, No. 1, pp.145-172.

Melton, C., Chen, J. and Lin, B. (2006) 'Organizational knowledge and learning: Leveraging it to accelerate the creation of competitive advantages', International Journal of Innovation and Learning, Vol. 3, No. 3, pp.254-266.

Moodyson, J., Coenen, L. and Asheim, B. (2008) 'Explaining spatial patterns of innovation: Analytical and synthetic modes of knowledge creation in the Medicon Valley lifescience cluster', Environment and Planning A, Vol. 40, pp.1040-1056. 
Morgan, K. (1997) 'The learning region: Institutions, innovation and regional renewal', Regional Studies, Vol. 31, No. 5, pp.491-503.

Pinto, H. (2009) 'The diversity of innovation in the European Union: Mapping latent dimensions and regional profiles', European Planning Studies, Vol. 17, No. 2, pp.303-326.

Pischke, J-S. (2001) 'Continuous training in Germany', Journal of Population Economics, Vol. 14, pp.523-548.

Prieto, I. and Revilla, E. (2006) 'Assessing the impact of learning capability on business performance: Empirical evidence from Spain', Management Learning, Vol. 37, No. 4, pp.499-522.

Ratanawaraha, A. and Polenske, K. (2007) 'Measuring geography of innovation: A literature review', In: Polenske, K. (ed.), The economic geography of innovation, (pp.30-59), Cambridge: Cambridge University Press.

Santarelli, E. and Piergiovanni, R. (1996) 'Analyzing literature-based innovation output indicators: The Italian experience', Research Policy, Vol. 25, pp.689-711.

Schneider, L., Günther, J. and Brandenburg, B. (2010) 'Innovation and skills from a sectoral perspective: A linked employer-employee analysis', Economics of Innovation and New Technology, Vol. 19, No. 2, pp.185-202.

Statistics Finland (2010) CVTS, Continuing vocational training survey 1999. Obtained through the Internet: http://www.stat.fi/index_en.html [accessed 11/6/2010].

Sternberg, R. and Arndt, O. (2001) 'The firm or region: What determines the innovation behaviour of European firms?', Economic Geography, Vol. 77, No. 4, pp.364-382.

Tessaring, M. and Wannan, J. (2004) Vocational education and training - Key to the future. Lisbon-Copenhagen-Maastricht: Mobilising for 2010, Luxembourg: Office for Official Publications of the European Communities.

Tödtling, F., Lehner, P. and Trippl, M. (2006) 'Innovation in knowledge intensive industries: The nature and geography of knowledge links', European Planning Studies, Vol. 14, No. 8, pp.1035-1058. 
Varsakelis, N. (2006) 'Education, political institutions and innovative activity: A crosscountry empirical investigation', Research Policy, Vol. 35, pp.1083-1090.

Weerawardena, J., O’Cross, A. and Julian, C. (2006) 'Does industry matter? Examining the role of industry structure and organizational learning in innovation and brand performance', Journal of Business Research, Vol. 59, pp.37-45.

Zwick, T. (2005) 'Continuing vocational training forms and establishment productivity in Germany', German Economy Review, Vol. 6, No. 2, pp.155-184. 


\section{Appendix 1}

Standings of countries in the rankings of innovation (measured in patents), CVT, and GDP.

\begin{tabular}{|c|c|c|c|c|c|}
\hline \multicolumn{6}{|c|}{ COUNTRY RANKINGS } \\
\hline \multicolumn{2}{|r|}{ INNOVATION } & \multicolumn{2}{|r|}{ CVT } & \multicolumn{2}{|r|}{ GDP } \\
\hline 1 & Finland & 1 & Denmark & 1 & Luxembourg \\
\hline 2 & Germany & 2 & Sweden & 2 & Norway \\
\hline 3 & Sweden & 3 & Finland & 3 & Denmark \\
\hline 4 & Luxembourg & 4 & United Kingdom & 4 & Ireland \\
\hline 5 & Netherlands & 5 & Netherlands & 5 & Sweden \\
\hline 6 & Denmark & 6 & France & 6 & Netherlands \\
\hline 7 & Austria & 7 & Ireland & 7 & United Kingdom \\
\hline 8 & Belgium & 7 & Norway & 8 & Finland \\
\hline 9 & United Kingdom & 9 & Luxembourg & 9 & Austria \\
\hline 10 & France & 10 & Czech Republic & 10 & Germany \\
\hline 11 & Norway & 11 & Belgium & 11 & Belgium \\
\hline 12 & Ireland & 12 & Germany & 12 & France \\
\hline 13 & Italy & 13 & Austria & 13 & Italy \\
\hline 14 & Slovenia & 14 & Slovenia & 14 & Spain \\
\hline 15 & Spain & 15 & Estonia & 15 & Greece \\
\hline 16 & Hungary & 16 & Spain & 16 & Portugal \\
\hline 17 & Czech Republic & 17 & Italy & 17 & Slovenia \\
\hline 18 & Lithuania & 18 & Portugal & 18 & Czech Republic \\
\hline 19 & Greece & 19 & Latvia & 19 & Hungary \\
\hline 20 & Estonia & 20 & Hungary & 20 & Estonia \\
\hline 21 & Latvia & 21 & Poland & 21 & Poland \\
\hline 22 & Portugal & 22 & Bulgaria & 22 & Lithuania \\
\hline 23 & Bulgaria & 22 & Greece & 23 & Latvia \\
\hline 24 & Poland & 24 & Lithuania & 24 & Romania \\
\hline 25 & Romania & 25 & Romania & 25 & Bulgaria \\
\hline
\end{tabular}




\section{Tables and figures}

Table 1. Spearman's correlation coefficients and p-values between innovation and variables depicting CVT.

\begin{tabular}{|l|c|c|c|c|}
\hline \multicolumn{5}{|c|}{ CORRELTION MATRIX } \\
\hline & $\begin{array}{c}\text { Innovation } \\
\text { (Patents) }\end{array}$ & $\begin{array}{c}\text { Enterprises } \\
\text { providing } \\
\text { CVT courses }\end{array}$ & $\begin{array}{c}\text { Employees } \\
\text { participating } \\
\text { in CVT courses }\end{array}$ & $\begin{array}{c}\text { Hours in } \\
\text { CVT courses }\end{array}$ \\
\hline Enterprises providing & 0.792 & & & \\
CVT courses & $<0.001$ & & & \\
\hline Employees participating & 0.777 & 0.856 & & \\
in CVT courses & $<0.001$ & $<0.001$ & 0.938 & \\
\hline Hours in CVT courses & 0.825 & 0.828 & $<0.001$ & \\
\hline Cost of CVT courses & $<0.001$ & $<0.001$ & 0.916 & 0.905 \\
& 0.739 & 0.855 & $<0.001$ & $<0.001$ \\
\hline
\end{tabular}
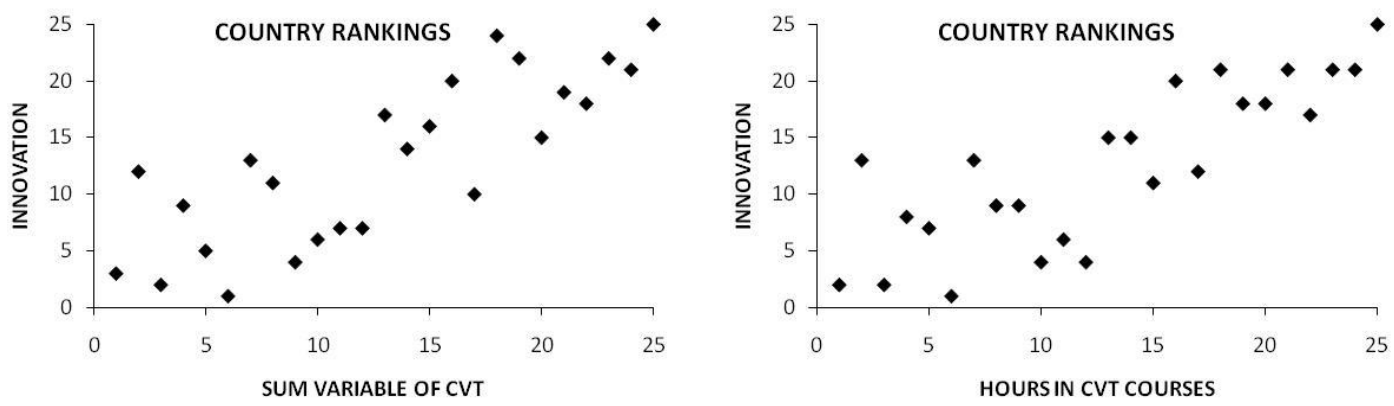

Figure 1. Standings of countries in the rankings of innovation and sum variable of CVT (left) and innovation and hours in CVT courses (right) (see Appendix 1). 

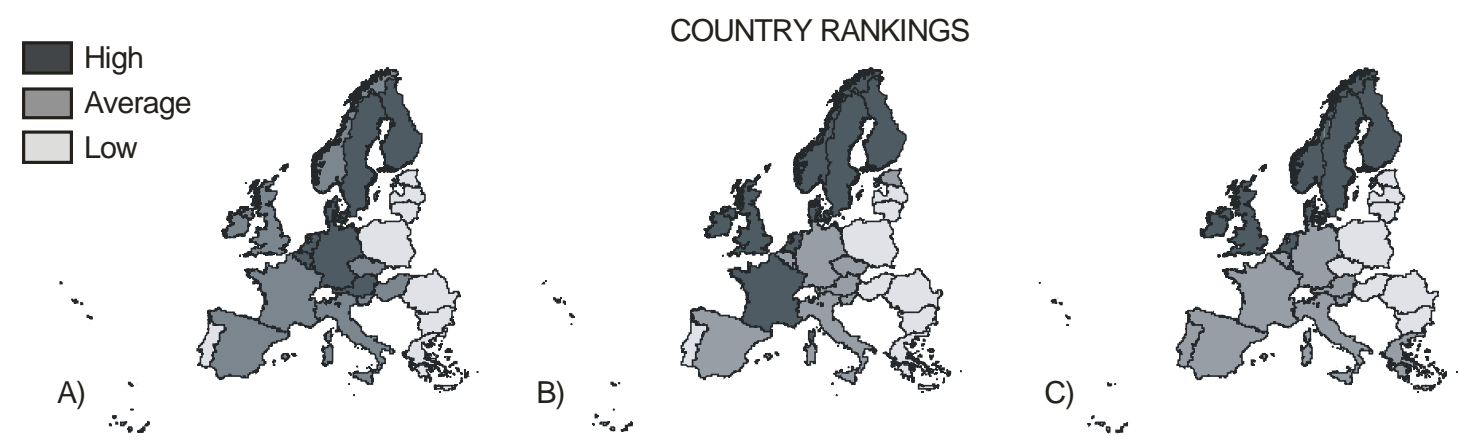

Figure 2. Standings of the counties in the rankings of A) innovation (as measured in patents), B) $C V T$, and C) GDP. 